\title{
Age and gender specific patterns of microfilaremia and circulating antigen with specific lymphocyte proliferative responses in Wucherereia bancrofti filariasis.
}

\author{
Amal, A. Al-Shafei ${ }^{1}$; Thanaa, M. El-Nashar ${ }^{1}$; Yousr, M. Ghoneame ${ }^{1}$; \\ Fatma, M.Selim ${ }^{2}$ and Gamal, N. Ahmed ${ }^{3}$.
}

Departments of Parasitology ${ }^{1}$, Microbiology ${ }^{2}$ and Tropical Medicine ${ }^{3}$ Faculty of Medicine, Al-Azhar University.

\begin{abstract}
A population from a W. bancrofti- endemic area was evaluated by use of microfilaria(Mf) and adult worm circulating antigen(CAg) enzyme linked immunosorbent assay to demonstrate the relation of these two parameters to age , gender and the clinical status (symptomatic or asymptomatic) of the examined individuals. In addition, antigen-driven $T$ cell proliferation was measured to study the effect of the clinical status and / or infection status on the host responsiveness in lymphatic filariasis. The results showed that the prevalence rates of each of the two markers are clearly age dependent and were significantly higher in males than females. The antigen prevalence rate was consistently higher than the microfilaria prevalence rate in all age groups. Among the asymptomatic and symptomatic patients, the direct relationship between $\mathrm{Mf}+$ and $\mathrm{CAg}+$ remained intact regardless of clinical status. Individuals positive for $\mathrm{CAg}$ had significantly lower lymphocyte proliferation responses to parasite antigen than did CAg-negative people. This study re-emphasizes the importance of CAg measurements for accurately assessing the clinical status of filariasis and demonstrates that the presence or absence of active infection, not clinical status is most closely associated with the immune responsiveness in lymphatic filariasis.
\end{abstract}

\section{Introduction}

A complex sequence of interact tions critical to the success of lymphatic filariae occurs shortly after $3^{\text {rd }}$ stage infective larvae are deposited on the skin during blood feeding by the mosquito vector Human exposure to infective larvae is associated with a broad spectrum of clinical, parasito logical and immunological outcomes. Chanteau et al. (1995) reported that the dynamics of acquisition of bancroftian filariasis in man are probably related to the intensity and the age of exposure.

During the initial or prepatent period of infection, large amount of soluble filarial antigens are excreted and secreted by developing parasites, especially during the molting process. These antigens are presumably proce ssed by antigen presenting cell (Pogonka et al., 1999) and detection of these antigens in peripheral blood would provide an accurate indication of active filarial infection (Mohsen et al., 1996). So antigenaemia could be used as a marker of infection and an indicator 
of worm burden, especially the number of female worms in the host(Ravindran et al., 2000) Until recently , unequiv ocal ascertainment of infection status could only be obtained by the demonstration of blood born Mf. However, assays that detect CAg in the absence of Mf have recently become available and enabled more precise classification of human infection such that nonpatent (Mf-CAg+) or light infections can be diagnosed (Weil et al.,1999).

Michael et al. (2001) stated that there might be at least two types of immunity operating in filariasis: one implicated in anti-infection immunity generated by experience of adult warms, the other involved in immune infection mediated pathology and based on cumulative experience of infective larvae. King et al. (2001) demonstrated that $\mathrm{T}$-cells play a critical role in regulating the immune response to nematode parasite and understanding of specificity of the $\mathrm{T}$-cell responses is essential for the elucidation of the mechanisms that underlie susceptibility and resistance to infection. Mahanty et al. (1996) reported that the impaired responses were assessed by lymphocyte proliferation.

The aim of the present work is to study the age and gender specific patterns of both microfilarial or circu lating antigen positivity, the effect of the clinical status (clinical manifestation vs. none) on microfilarial and circula ting antigen positivity and the effect of the clinical status and / or infection status on host responsiveness in W.bancrofti infection.

\section{Materials and methods}

105 residents of Tohoria village, Al- Qalubiya governorate, a filarial endemic area in the Nile Delta, $40 \mathrm{~km}$ northeast of Cairo were randomly selected and enrolled in the present study. Demographic information (age and sex) was collected as described by Bockaria et al. (1998). Standardized histories were obtained and physical examination for clinical signs of lymphatic disease attributable to $W$. bancrofti infection was performed according to recommendations outlined by WHO (1984). Venous blood samples were collected for detection of microfilaria, circulating antigen and for lymphocyte proliferation assay. The study population was divided into groups of 10 year age intervals.

\section{Microfilaria detection:}

Microfilaremia was determined by filtration of $1 \mathrm{ml}$ heparinized venous blood obtained between 10 p.m. and 2 a.m. through Nuclepore membranes of 5um pore size (Pleasanton, CA, USA) as in Dennis et al. (1976). Membrane filters were Giemsa stained and microscopically examined for Mf.

\section{Preparation of adult parasite antigen:}

The adult worm antigen was prepared according to Maria et al (1993) from Dirofilaria immitis adult worms separated from the hearts of infected dogs. The worms were washed in PBS, then freezed, thawed and crushed in a mortar for 5 minutes using tris buffer $\mathrm{PH}$ 8.3. The homogenate was shacked over night at $4^{\circ} \mathrm{C}$. Next morning it was centrifuged at 10,000 $\mathrm{g}$ for 15 minutes. The supernatant was aliquted and stored in $-20^{\circ} \mathrm{C}$. The protein concentration was determined by Lowry et al. (1951).

Detection of CAg by ELISA (Mosen et al., 1996):

Hyper-immune serum against Dirofilaria immitis adult antigen was prepared in 2 white New-Zealand rabbits by subcutaneous injection of 0.5 
mg protein antigen /rabbit with equal volume of complete Freund's adjuvant (Weil et al., 1984). One week later, two booster doses were given with oneweek interval. Sera were collected one week after the final booster injection. Isolation of gamma-globulin fraction of antiserum was obtained using protein-A Sepharose chromatography (Hudson and Hay, 1980). The gamma-globulin fraction was conjugated with horseradish peroxidase (HRP) type IV enzyme (Sigma). The unconjugated antiserum was used to coat the plate in a concentration of $10 \mathrm{ug} / \mathrm{ml}$ with serum diluted 1:20. The HRP-conjugated polyclonal was then added to complete the sandwich with subsequent addition of the substrate. The optical density (OD) readings were read on $492 \mathrm{~nm}$ wavelength on a titertek ELISA-reader. Patients was considered positive if OD reading was greater than 0.065 (mean \pm 3 S.D. of that observed with the panel of control sera).

\section{lymphocyte proliferation assay}

Freshly isolated peripheral blood mononuclear cells (PBMC) separated from heparinized venous blood by density gradient centrifugation on Ficoll-Hypaque were used. PBMC $\left(2 \times 10^{6}\right.$ cell $\left./ \mathrm{ml}\right)$ were cultured in complete PRMI (PRMI 1640 medium supplemented with $4 \mathrm{~m} M$ L-glutamine, $10 \%$ fetal calf serum, $100 \mathrm{U} / \mathrm{ml}$ penicillin and $100 \mathrm{ug} / \mathrm{ml}$ streptomycin) at $37^{\circ} \mathrm{C}$ in $5 \% \mathrm{Co} 2$ incubator with 8 $\mathrm{ug} / \mathrm{ml}$ adult filarial antigen or $2 \mathrm{ug} / \mathrm{ml}$ phytohemagglutinin (PHA), as a control medium . All supernatants were collec ted at $48 \mathrm{~h}$ and immediately frozen at $70^{\circ} \mathrm{C}$ until use. Antigen-driven $\mathrm{T}$ cell proliferation was measured using $10^{5}$ cells per culture well as described by (King et al., 1993). Cells were harvested onto filters and counted by liquid scintillation to determine counts per minute $(\mathrm{cpm})$ incorporated. Data were expressed as stimulation indices (SI), calculated by dividing the mean cpm of stimulated cells by the mean cpm of cells incubated with medium.

\section{Statistical analysis:}

Statistical analysis was dame by using the student's test $\mathrm{P}<0.05$ were considered significant.

\section{Results}

Table (1) showed that the prevalence of microfilaria and circula ting antigen positive patients was gene rally increased in males than in females. The age prevalence of antigenemia was consistently higher than microfilarenia as shown in Fig (1), the differences observed between the two detection methods (Mf and CAg) continued through all age groups, with a mean difference between the two curves of 19.5\%. Fig (2) and Fig (3) revealed that the percentage of Mf and CAg positive subjects increased with age for males and females reaching a peak in the 3039year age group. After a slight decrease at 40-49 years, the prevalence in males and females increased, however, in the $>60$ year age group, the sex diverged significantly $(p>0.001)$ with males having a higher rate than females. Not unexpectedly, individuals $<19$ years had Mf and CAg prevalence that were significantly lower $(p<0.01)$ than those of all age groups.

As shown in table (2), 27 out of the 105 individuals included in the study have objective clinical manifest ations of lymphatic filariasis (18 with hydrocele, 5 with elephantiasis and 4 with both hydrocele and elephantiasis). Among those patients, 13 were Mf+, and all but one of these were also CAg+. Those with hydrocele alone were more likely to be Mf+ (10 of $18 ; 55 \%)$ than those with elephantiasis alone (1 of 
5; 20\%). The results also showed that three of the Mf- patients were CAg+. As regards to the asymptomatic individuals, forty-three were $\mathrm{CAg}+$ (twenty-three with $\mathrm{MF}+$ ). So the direct relationship between $\mathrm{Mf}$ positivity and $\mathrm{CAg}$ positivity remained intact regardless of clinical status.

The lymphocyte proliferative responses to AWA in different clinical status of the examined individuals were represented in table (3). CAg+ subjects had significantly lower proliferative responses than did CAg-ones (Geometric mean SIs and SDs were $1.5 \pm 1.7 \& 2.6 \pm 0.3$ in asymptomatic and symptomatic $\mathrm{CAg}+$ subjects respectively and $3.1 \pm 2.4 \& 3.2 \pm 2.6$ in asymptomatic and symptomatic $\mathrm{CAg}$ respectively; $\mathrm{p}=0.002$ ). So a negative correlation was found between proliferation responses to adult worm antigen and CAg levels.

Table (1): Demographic data of the studied individuals with microfilarial (Mf) and circulating antigen $(\mathrm{CAg})$ prevalence:

\begin{tabular}{|c|c|c|c|c|c|c|}
\hline $\begin{array}{l}\text { No. of the } \\
\text { studied } \\
\text { peoples }\end{array}$ & Males (\%) & Females $(\%)$ & \multicolumn{2}{|c|}{$\begin{array}{l}\text { No. of Mf }+(\%) \\
\text { Total } 43(40.9 \%)\end{array}$} & \multicolumn{2}{|c|}{$\begin{array}{c}\text { No. of CAg }+(\%) \\
\text { Total } 55(52.3 \%)\end{array}$} \\
\hline \multirow[t]{2}{*}{105} & \multirow[t]{2}{*}{$45 \quad(42.9 \%)$} & \multirow[t]{2}{*}{$60 \quad(57.1 \%)$} & $\begin{array}{c}\text { Males } \\
(\%)\end{array}$ & $\begin{array}{c}\text { Females } \\
(\%)\end{array}$ & $\begin{array}{c}\text { Males } \\
(\%)\end{array}$ & $\begin{array}{c}\text { Females } \\
(\%)\end{array}$ \\
\hline & & & $\begin{array}{c}25 \\
(55.5 \%)\end{array}$ & $\begin{array}{c}18 \\
(30 \%)\end{array}$ & $\begin{array}{c}28 \\
(62.2 \%)\end{array}$ & $\begin{array}{c}27 \\
(45 \%)\end{array}$ \\
\hline
\end{tabular}

Fig. (1): Age specific prevalence's of microfilaremia and antigenemia.




Fig. (2): Age specific prevalences of microfilaremia according to sex

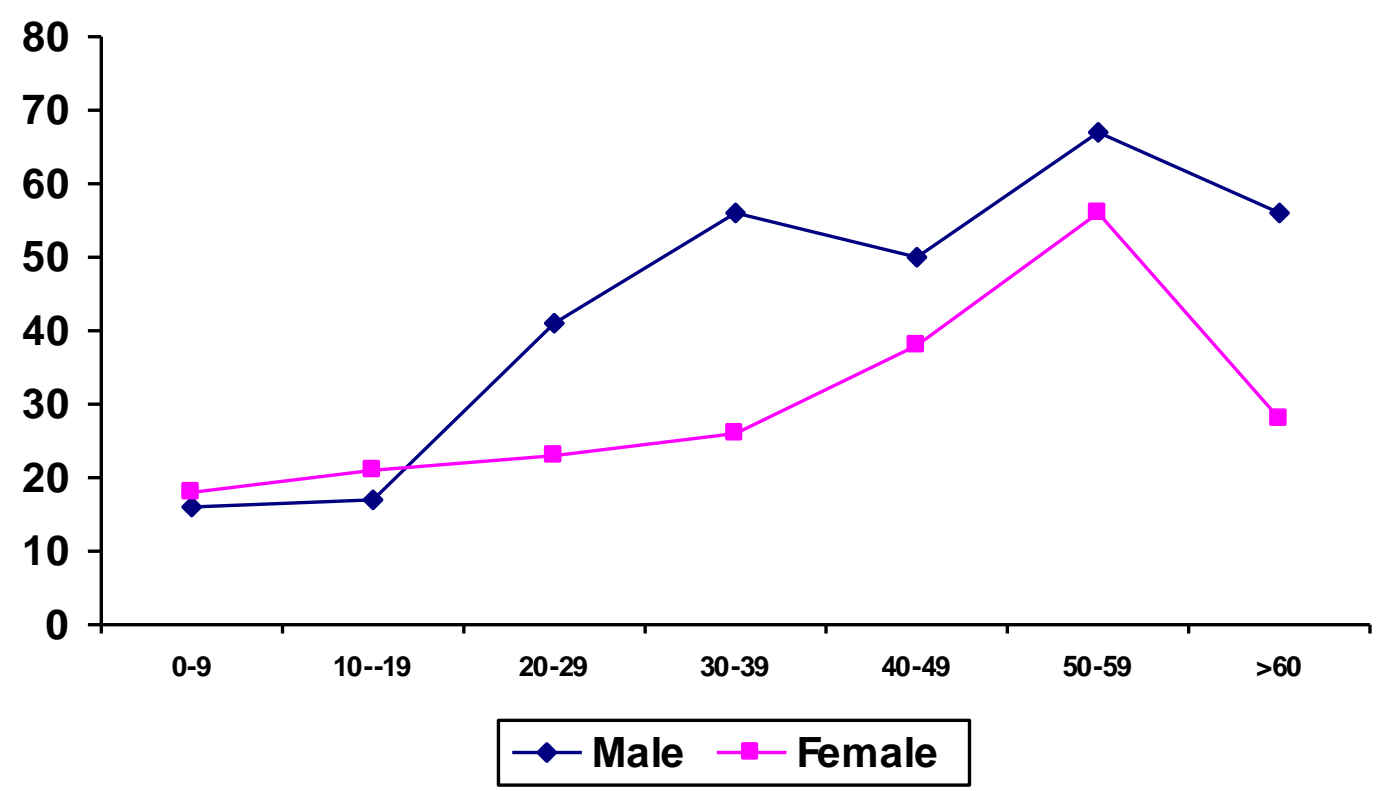

Fig. (3): Age specific prevalence's of antigenemia according to sex.

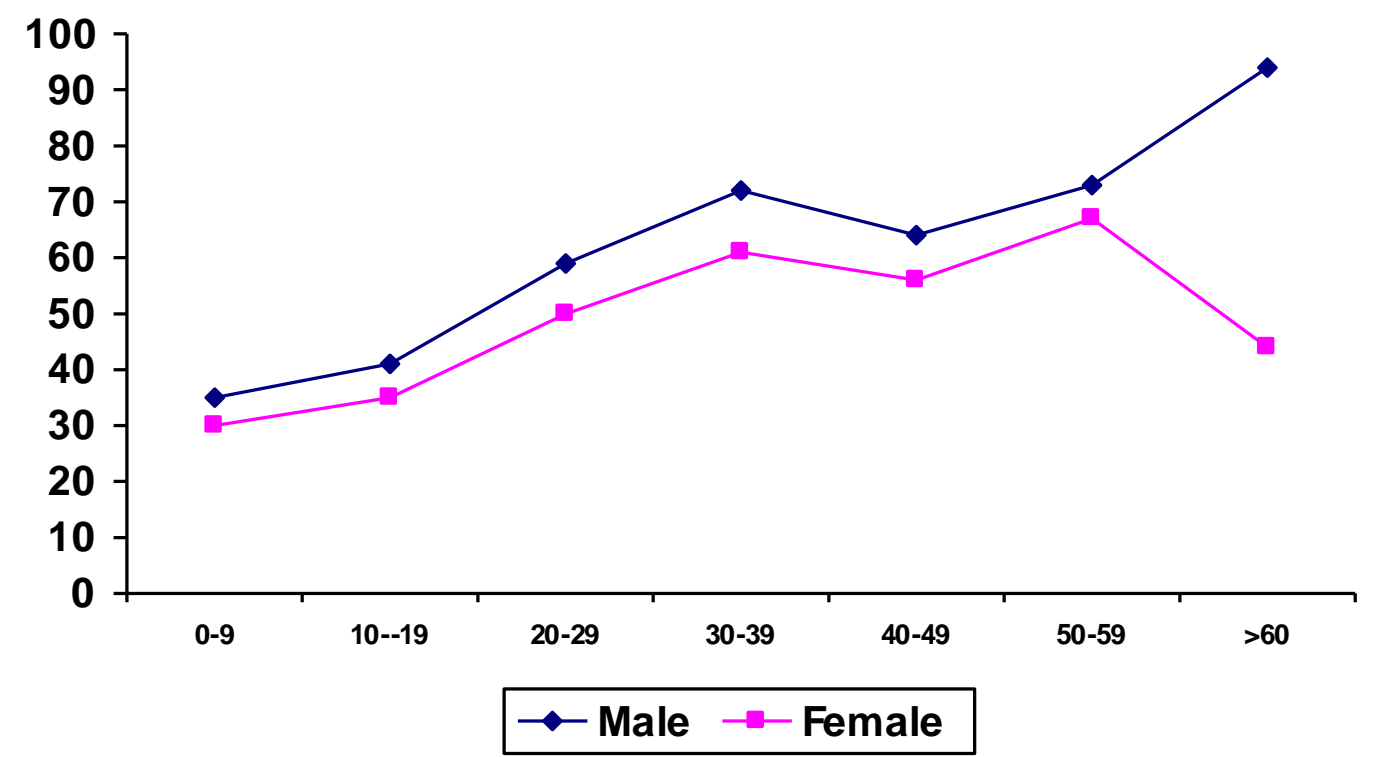

Table (2): Microfilarial and circulating antigen prevalence in different clinical status of the studied individuals.

\begin{tabular}{|c|c|c|c|c|c|}
\hline Clinical status & $\begin{array}{c}\mathrm{CAg}- \\
\mathrm{MF}-\end{array}$ & $\begin{array}{c}\mathrm{CAg}- \\
\mathrm{MF}+\end{array}$ & $\begin{array}{c}\mathrm{CAg}+ \\
\mathrm{MF}-\end{array}$ & $\begin{array}{c}\mathrm{CAg}+ \\
\mathrm{MF}+\end{array}$ & Total \\
\hline Asymptomatic & 35 & - & 20 & 23 & 78 \\
\hline Symptomatic & & & & & \\
Hydrocele & 7 & - & 1 & 10 & 18 \\
Elephantiasis & 3 & - & 1 & 1 & 5 \\
Hydrocele/elephantiasis & 1 & 1 & 1 & 1 & 4 \\
\hline Total & 46 & 1 & 23 & 35 & 105 \\
\hline
\end{tabular}


Table (3) Lymphocyte proliferation to adult worm antigen in different clinical status of the examined persons.

\begin{tabular}{|c|c|c|c|}
\hline \multicolumn{2}{|c|}{ Asymptomatic } & \multicolumn{2}{c|}{ Symptomatic } \\
\hline $\begin{array}{c}\text { CAg- } \\
\text { Mean } \pm \text { SD }\end{array}$ & $\begin{array}{c}\text { CAg+ } \\
\text { Mean } \pm \text { SD }\end{array}$ & $\begin{array}{c}\text { CAg- } \\
\text { Mean } \pm \text { SD }\end{array}$ & $\begin{array}{c}\text { CAg+ } \\
\text { Mean } \pm \text { SD }\end{array}$ \\
\hline $3.1 \pm \mathbf{2 . 4}$ & $1.5 \pm 1.7$ & $3.2 \pm 2.6$ & $2.6 \pm 0.3$ \\
\hline
\end{tabular}

\section{Discussion}

Lymphatic filariasis, which is caused by the helminthes Wuchereria bancrofti and Brugia malai, affects more than 100 million people worldwide (Michael et al., 1996). In recent years, the prevalence of bancroftian filariasis has dramatically increased in Nile Delta of Egypt (Farid et al., 1997). It is characterized by a broad range of clinical presentations among the infected individuals (ElSerougi et al., 2000). To assess the infection status in a locality, several assessment procedures have been used. These procedures include: recording obvious clinical signs of filariasis such as hydrocele or elephantiasis (Pani et al., 1997; Gyapong et al., 1998), microfilarial detection by nocturnal blood samples (Harb et al., 1993) and detecting circulating filarial antigen (Weil et al., 1997). Recording clinical cases is simple but not very accurate in terms of recent infection (Itoh et al., 2001) Microfilaremia lacks sensitivity, owing to long prepatent period in lymphatic filariasis, the impeded excess of $\mathrm{Mf}$ to the blood circulation in cases of lymphatic damage and the possible suppression of microfilaremia and microfilarial production by immune mechanisms(WHO,1984). Michael et al. (1996) and Freedman (1998) reported that MF and aMF persons are equally likely to have pathologic manifestation of disease and the distinction between these groups may not as sharp as was previously believe. With the recent use of CAg assays, as a sensitive determinant of the presence of adult parasites, $15-60 \%$ of those with clinical pathology have been shown to be actively infected (Al-buquerque et al., 1995). Mohsen et al. (1996) and Rocha et al. (1996) considered that the CAg assay is nonetheless a far more accurate tool for assessing infection status than is Mf or any other method of rapid assessment.

The current study revealed that $\mathrm{CAg}$ prevalence rate was consistently higher than Mf prevalence rate in all age groups, with many of infected individuals in some age groups, children and adolescents, being misclassified. Steel et al. (2001) reported that the prevalence of infection in the popu lation was 20\% higher when determined by CAg positivity than when determined by MF as non-patent (MF-CAg+) or light infections can be diagnosed. This finding has particular significance because the general ineffectiveness of diethylcarbamazine to reverse lymphatic damage in treated adults emphasizes the importance of targeting individuals infected early to prevent the subsequent development of clinical status.

The present study showed that the prevalence rates of $\mathrm{Mf}+$ and $\mathrm{CAg}+$ are clearly age dependent. Two distinct 
peaks were observed across the population' $s$ age profile indicating that adult worm burden was fluctuating with age. These results agree with Fulford et al. (1998) who found similar fluctuations in a study of patients with schistosomiasis. They have attributed these fluctuations to changes in levels of certain hormones, particularly dehydro epiandrosterone. Gad et al. (1994) found microfilariae in all age groups while Ramzy et al., (1994) reported that Mf prevalence rates increased rapidly between ages 5-40 then tends to decrease slightly in older age groups.

The current study revealed that CAg and Mf prevalence were higher in males than females. The major sex differences were during the reprodu ctive year (16-40 years) and in the $>60$ years old .The differences observed between the gender in the present study have been demonstrated in other studies of bancroftian filariasis (Brabin, 1990; Dutta and Diesfeld, 1994; Haarbrink et al., 1999 and Steel et al., 2001) and in other helminth infections (Nakanishi et al., 1989 and Bell et al., 1999). Brabin (1990) have suggested a possible pregnancy-related mechanism for the lower disease rates found in females but Alexander and grenefell (1999) have found no such connection. Cultural factors causing males to be more exposed to Mf at an earlier age or even variations in closing may account for gender differences in disease prevalence( Kaur, 1997), but Steel et al. (1996) found no specific explanation for this differences. In contrary to our results, Gad et al. (1994) found that Mf prevalences were the same in males and females.

Lymphatic filariasis caused by Wuchereria bancrofti is characterized by a broad range of clinical presen tations among the infected individuals (El-Serougi et al., 2000). 27 out of 105 individuals included in the study have objective clinical manifestations of lymphatic filariasis. With the use of CAg, 15 out of those symptomatic patients have CAg+. This is in agreement with Al-buquerque et al. (1995) who found that $15-60 \%$ of those with clinical pathology have been shown to be actively infected. The geometic mean levels of CAg in the present study, between those with clinical manifestations and those with asymptomatic infection, showed no significance differences and the direct relationship between $\mathrm{Mf}+$ and $\mathrm{CAg}+$ remained intact regardless of clinical status.

Studies on immune responses to parasites have been undertaken in filariasis with a view to understand protective immunity, pathogenesis of the disease process and mechanisms of immune deviation. (Mohanty et al., 2001). Helminthes and protozoan parasites modulate immune responses of their host at both the B and T cell levels. Lymphocyte proliferation assay have been done in all persons enrolled in this study. The results revealed that individuals positive for $\mathrm{CAg}$ had significantly lower lymphocyte prolife ration responses to parasite antigen than did CAg negative people, regardless of clinical status. So, there was a negative correlation between proliferation responses to adult worm antigen and CAg levels. This was in agreement with Steel et al. (2001) who demonstrated that the CAg+ individ uals, not just those with MF, had little or no proliferative response to parasite antigen. They attributed that to the presence of viable adult worms themselves rather than their absolute number that may be the determinant in immune responsiveness. Liu and Weller (1992) referred this T-cell hyporesponsiveness to the evoking of $\mathrm{IgG} 1$, 
IgG2 and IgG3 antibody levels as a result of the passive reaction to naturally dying adult worms. These antibodies mediate inflammatory reactions to disintegrating adult worms in the lymphatics. However, the remaining live worms are able to avoid the effects of these inflammatory reactions (by releasing molecules that inhibit cell adherence, killing or both) and survive. The presence of the live worms can result in T-cell hyporesponsiveness. While Maria et al. (1993) attributed the low antigen specific $\mathrm{T}$ - cell proliferation to the elevation of the $\operatorname{IgE}$ that mediates killing of mature worms. This response is episodic and may alternate with new waves of parasites establishing themselves in the patients, resulting in the observed high antifilarial IgG4 and low T-cell proliferation. King et al. (2001) reported that the defects in antigen-presenting cell function appear to participate in this acquired immune hypo-responsiveness. These hyporesponsiveness probably plays a significant role in maintaining the parasite free from immune attack in vivo (Mahanty et al., 1996).

\section{References}

1. Al-buquerque, M.F.; Marzochi, M.C.; Sabroza, P.C.; et al. (1995): Bancroftian filariasis in two urban areas of Recife, Brazil: pre-control observa tions on infection and disease. Trans. R. Soc. Trop. Med. Hyg., 89: 373-377.

2. Alexander, N. and Grenefell, B. (1999): The effect of pregnancy on Wuchereria bancrofti microfilarial load in humans. Parasitology, 119: 151-156.

3. Bell, R.; Adams, L.; Coleman, S.; Negrao-Correa, D. and Klei, T. (1999): Brugia pahangi: quantitative analysis of infection in several inbred rat strains. Exp. Parasitol., 92: 120-130.

4. Bockaria, M.; Alexander, N. Hun, P.; Dimber, Z.; Bockarie, F.; Iban, E.; Alpers, M. and Kazura, J. (1998) :
Randomized community- based trial of annual single-dose diethylcarbamazine with or without ivermectin against Wucheraria bancrofti infection in human beings and mosquitoes. Lancet, 351: 162.

5. Brabin, L. (1990): Sex differentials in susceptibility to lymphatic filariasis and implications for maternal child immu nity. Epidemiol. Infect., 105: 335-353.

6. Chanteau, S.; Glaziou, P.; Plichart, C.; Luquiaud, P.; Moulia- Pelat, J.; Nguyen, L. and Cartel, J. (1995): Wuchereria bancrofti filariasis in French Polynesia: age-specific patterns of microfilaremia, circulating antigen and specific $\operatorname{IgG}$ and $\operatorname{IgG} 4$ responses according to transmission level. Int. J. Parasitol., 25: 81-85.

7. Dennis, D.T.; Mc Connel, E.T. and White, G. (1976): Bancroftian filariasis and memberane filters: night surveies necessary? Am. J. Trop. Med. Hyg., 25: 257-262.

8. Dutta, S. and Diesfeld, H. (1994): Evidence of sex variations in microfilaraemia and fluorescent and antibody titre level at puberty in a Wuchereria bancrofti endemic area. J. Commun. Dis., 26: 43-51.

9. El-SEROUGI, A.O.; Fikry, A.A.; Farrag, A.M. and Saleh, W.A. (2000): Evaluation of the IgG4 in Egyptian bancroftian filariasis. J. Egypt. Soc. Parasitol., 30: 59-67.

10. Farid, H.A.; Morsy, Z.S.; Gad, A.M. Ramzy, R.M.; Faris, R. and Weil, G.J. (1997): Filariasis transmission potential of mosquitoes to humans of different age groups. J. Egypt. Soc. Parasitol., 27: 355-364.

11. Freedman, D.O. (1998): Immune dynamics in the pathogenesis of human lymphatic filariasis. Parasitol. Today, 14: 229.

12. Fulford, A.; Webester, M.; Ouma, J.; Kimani, G. and Dunne, D. (1998): Puberty and age - related changes in susceptibility to schistosome infection. Parasitol. Today, 14: 23-26.

13. Gad, A.M.; Feinsod, F.M.; Soliman, B.A.; Nellson, G.O.; Gibbs, P.H. and Shoukry, A. (1994): Exposure 
variables in bancroftian filariasis in the Nile Delta. J. Egypt. Soc. Parasitol., 24: 439-455.

14. Gyapong, J.O.; Webber, R.H.; Morris, J.; and Bennett, S. (1998): Prevalence of hydrocele as a rapid diagnostic index for lymphatic filariasis. Trans. R.Soc. Trop. Med. Hyg., 92: 40-43.

15. Haarbrink, M.; Terhell, A.; Abadi, K.; Asri, M.; De Medeiros, F. and Yazdanbakhsh, M. (1999): Antifilarial IgG4 in men and women living in Brugia malayi -endemic areas. Trop. Med. Int. Health, 4: 93-97.

16. Harb, M.; Faris, R. Gad, A.; Hafez, O.; Ramzy, R. and Buck, A. (1993): The resurgence of lymphatic filariasis in Nile Delta. Bull. WHO., 71: 49-54.

17. Hudson, L. and Hay, F.C. (1980): Ion exchange chromatography. In: 'Practical Immunology" $2^{\text {nd }}$ ed. Blackwell Scientific Publication, Oxford, London, Edinburgh, Boston and Melbourne.

18. Itoh, M.; Weerasooriya, M.; Gunawardena, N.; Anantabhruti, M.; Tesana, S.; Rattanaxay, P.; Fujimaky, Y. and Kimura, E. (2001): Sensitive and specific enzyme- linked immunosorbent assay for the diagnosis of Wuchereria bancrofti infection in urine samples. Am. J. Trop. Med. Hyg., 65: 362-365.

19. Kaur, V. (1997): Tropical diseases and women. Clin. Dermatol., 15: 171-178.

20. King, C.L.; Connelly, M.; Alpers, M.P.; Bockarie, M. and Kazura, J.W. (2001): Transmission intensity determines lymphocyte responsiveness and cytokine bias in human lymphatic filariasis. J. Immunol., 166: 7427-7436.

21. King, C.L.; Mahanty, S.; Kumaraswami, V.; Abrams, J.S.; Regunathan, J.; Jayaraman, K.; Ottesen, E.A. and Nutman, T.B. (1993): Cytokine control of parasitespecific anergy in human lymphatic filariasis: preferential induction of a regulatory $\mathrm{T}$ helper type 2 lymphocyte subset. J. Clin. Invest., 92: 1667-1673.

22. Liu, L. X. and Weller, P.F. (1992): Intravascular filarial parasites inhibit platelet aggregation. Role of parasitederiped prostanoids. J.Clin. Invest., 89: 1113-1120.

23. Lowry, O.; Rosebrough, N. and Farr, A. (1951): Protein measurements with the folin phenol reagent. J. Biol. Chem., 103: 265-275.

24. Mahanty, S.; Luke, H.E.; Kumaraswami, V.; Narayanan, P.R.; Vijayshekaran, V. and Nutman, T.B. (1996): Stage - specific induction of cytokines regulate the immune response in lymphatic filariasis. Experimental parasitology, 84: 282-290.

25. Maria, Y.; William, A.; Yvonne, C.; Erliyani, S.; Agenes, T.; Angelique, W.; Murray, E.; Felix, P. and Rick, M.( 1993) : $\mathrm{T}$ cell responsiveness correlates differentially with antibody isotype levels in clinical and asymptomatic filariasis J. Infect. Dis.; 167: 925-931.

26. Michael, E.; Bundy, D. and Grenfell, B. (1996): Reassessing the global prevalence and distribution of lymphatic filariasis. Parasitol., 112: 409-428.

27. Michael, E.; Simonsem, P.E.; Malecela, M.; Jaoko , W.J.; Pedersen, E.M.; Mukoko, D.; Rwegoshora, R.T. and Meyrowitsch, D.W. (2001) : Transmission intensity and the immunoepidemiology of bancroftian filariasis in East Africa. Parasite Immunol., 23: 373-388.

28. Mohanty, M.C.; Satapathy, A.K.; Sahoo, P.K. and Ravindran, B. (2001): Human bancroftian filariasis- a role for antibodies to parasitic carbohydrate. Clin. Exp. Immunol., 124: 54-61.

29. Mohsen , M.H.; Magdy, A.T. Reda, M.R.; Ala elddin ,N.A.; Mohammed, H.A.; Nabil, S.H.; Amr, F.E.; Adel, A.M. and Ahmed, M.I. (1996) : Evaluating the detection of circulating filarial antigen in diagnosis of bancroftian filariasis and filarial hydrocele .J. Egypt. Soc. Parasitol., 26: 687-696.

30. Nakanishi, H.; Horii, Y. and Fujita, K. (1989): The role of macrophages on the expression of sex difference in the 
susceptibility to Brugia pahangi infection in C57PL/6 mice. J. Helminthol., 63: 213-217.

31. Pani, S.P.; Srividya, A.; Krishnamoorthy, K.; Das, P.K. and Dhanda, V. (1997): Rapid assessment procedures (RAP) for lymphatic filariasis. Nat. Med. J. India, 10: 19-22.

32. Pogonka, T.; Oberlander, V.; Marti, T. and Lucius, R. (1999): Acanthocheilonema vitaeae characteri zation of a molt- associated excretory / secretory $18-\mathrm{kDa}$ protein. Exp. Parasitol., 93: 73-77.

33. Ramzy, R.M.; Hafez, O.N.; Gad, A.M.; Faris, R.; Harb, N.; Buch, A.A. and Weil, G.J. (1997) : Efficient assessment of filariasis endemicity for filarial antigenemia in a sentinel popu lation . Trans. R. Soc. Trop. Med. Hyg., 88: 41-44.

34. Ravindran, B.; Satapathy, A.K.; Sahoo, P.K. and Babu Jeddam, J.J. (2000): Protective immunity in human bancroftian filariasis: inverse relatio nship between antibodies to microfil arial sheath and circulating filarial antigens. Parasite immunol., 22: 633637.

35. Rocha, A.; Addis, D.; R.ibeiro, M. Noroes, J.; Baliza, M.; Medeiros, Z. and Dreyer, G. (1996): Evaluation of the $\mathrm{Og} 4 \mathrm{C} 3$ ELISA in Wuchereria bancrofti infection: infected persons with undetectable or ultra- low microfilarial densities. Trop. Med. Int. Health, 1: 859-864.

36. Steel, C.; Guinea, A. and Ottesen, E. (1996): Evidence for protective immunity to Wuchereria bancrofti in the Cook Islands .J. Infect. Dis., 174: 598-605.

37. Steel, C.; Ottesen, E.; Weller, P. and Nutman, T. (2001): Worm burden and host responsiveness in Wuchereria bancrofti infection: use of antigen detection to refine earlier assessment from the South Pacific. Am. J. Trop. Med. Hyg., 65: 498-503.

38. Weil, G.J.; Lammie, P.J. and Weiss, N. (1997): The ICT filariasis test: a rapid- formate antigen test for diagnosis of bancroftian filariasis. Parasitol. Today, 13: 401-404.

39. Weil, G.J.; Malane, M.S. and Powers, K.J. (1984): Detection of circulating parasite antigens in canine dirofilariasis by counter immunolectrophoresis. Am. J. Trop. Med. Hyg., 33:425-430.

40. Weil, G.J.; Ramzy, R.M.; El Setouhy, M.; Kandil, A.M.; Ahmed, E.S. and Faris, R. (1999) : A longitudinal study of bancroftian filariasis in the Nile Delta of Egypt : base line data and one year follow -up Am. J. Trop. Med. Hyg., 61:53-58.

41. WHO (1984) : Lymphatic filariasis, Fourth Report of the WHO Export Committee on filariasis World Health Organization, Tech. Rep. Ser., No. 702, Geneva. 


\section{دراسة علاقة كلا من الميكروفيلاريا والاتتجين بالعمر والنوع

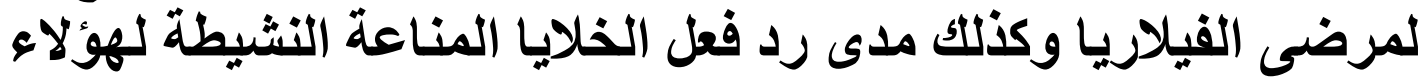 المرضى}

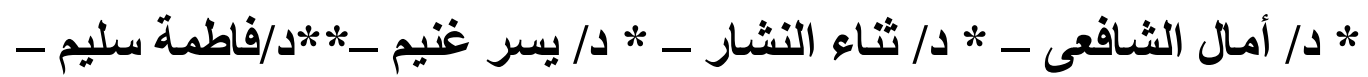
*****

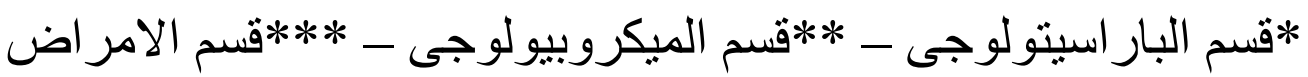

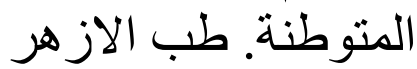

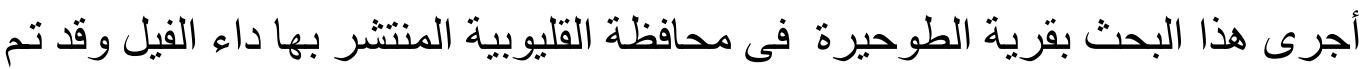

اختبار 105 من أشخاص هذه القرية اختيار ا عشو ائيا ( 45 من الذكور ،60 من الأنية الاناث) وقد

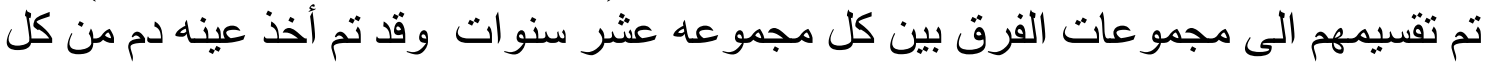

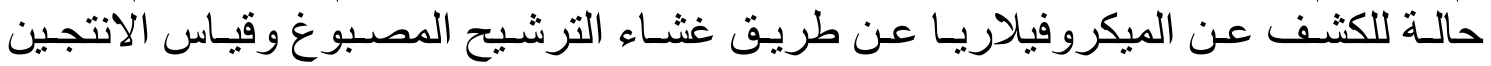

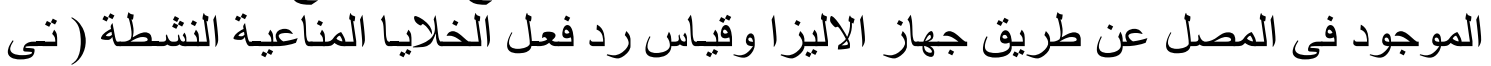

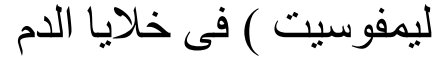

\section{وقد أظهرت النتائج ما يلحى :}

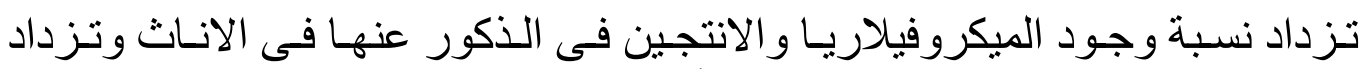



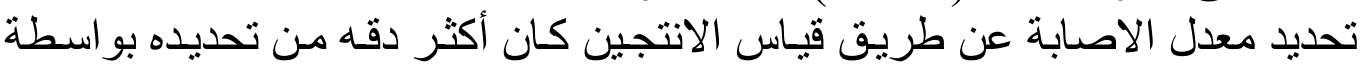
وجود الميكروفيلاريا.

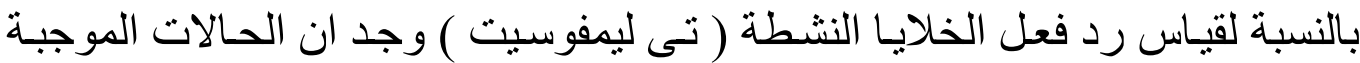

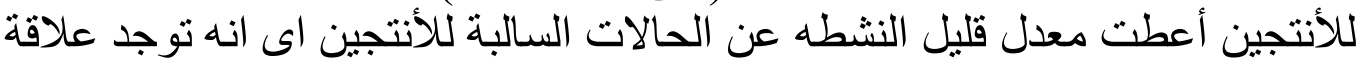

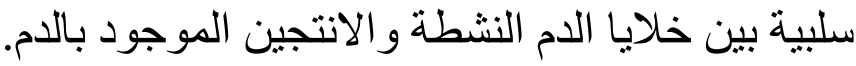

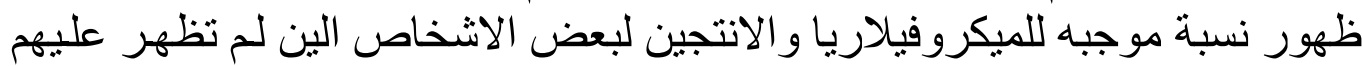

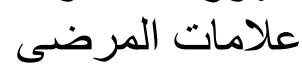

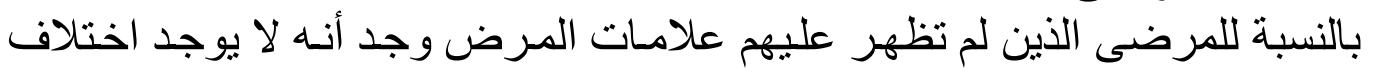

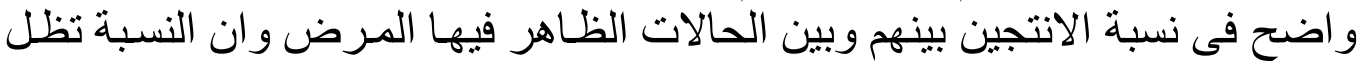

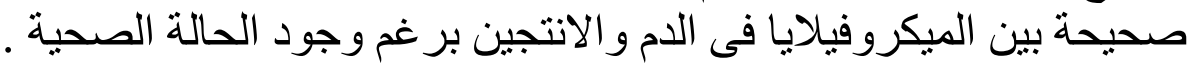

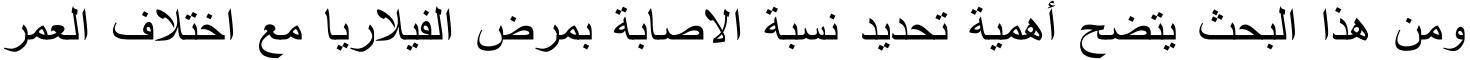

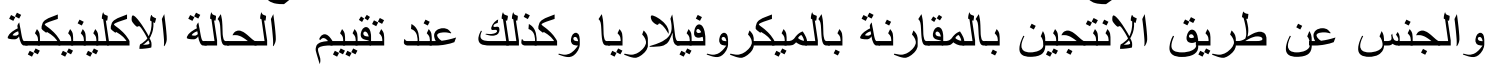

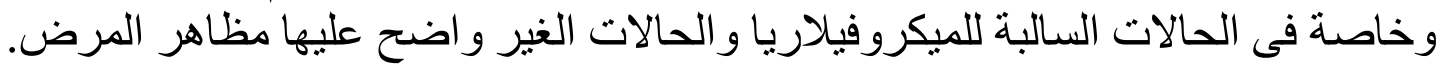

